Short Research Communication

\title{
Lycopene Treatment of Prostate Cancer Cell Lines Inhibits Adhesion and Migration Properties of the Cells
}

\author{
Simone Elgass, Alan Cooper and Mridula Chopra ${ }^{\bowtie}$ \\ School of Pharmacy and Biomedical Sciences, IBBS, University of Portsmouth, Portsmouth, UK
}

$\square$ Corresponding author: Dr Mridula Chopra, School of Pharmacy and Biomedical Sciences, St Michael's Building, White Swan Road, University of Portsmouth, Portsmouth PO1 2DT. Tel: 02392842796; Fax: 02392843565; Email: Mridula.Chopra@port.ac.uk

(c) Ivyspring International Publisher. This is an open-access article distributed under the terms of the Creative Commons License (http://creativecommons.org/ licenses/by-nc-nd/3.0/). Reproduction is permitted for personal, noncommercial use, provided that the article is in whole, unmodified, and properly cited.

Received: 2014.03.17; Accepted: 2014.05.23; Published: 2014.07.02

\begin{abstract}
Background: Consumption of lycopene through tomato products has been suggested to reduce the risk of prostate cancer. Cellular adhesion and migration are important features of cancer progression and therefore a potential target for cancer interception. In the present study we have examined the in vitro effect of lycopene on these processes.

Methods: Prostate cancer cell lines PC3, DUI45 and immortalised normal prostate cell line PNT-2 were used. The adhesion assay consisted of seeding pre-treated cells onto Matrige/ ${ }^{\mathrm{TM}}$, gently removing non-adherent cells and quantitating the adherent fraction using WST-I. Migratory potential was assessed using ibidi ${ }^{\mathrm{TM}}$ migration chamber inserts, in which a cell-free zone between two confluent areas was allowed to populate over time and the migration measured.

Results: 24 hour incubation of prostate cell lines with $1.15 \mu \mathrm{mol} / \mathrm{l}$ lycopene showed a $40 \%$ reduction of cellular motility in case of PC 3 cells, $58 \%$ in DUI 45 cells and no effect was observed for PNT2 cells. A dose related inhibition of cell adhesion to a basement membrane in the form of Matrige $^{\mathrm{TM}}$ was observed in all three cell lines and it reached statistical significance for PC3 and PNT2 cells at lycopene concentrations $\geq 1.15 \mu \mathrm{mol} / \mathrm{l}$. However, in case of DUI45, only a concentration of $2.3 \mu \mathrm{mol} / \mathrm{l}$ showed a significant reduction.

Conclusion: This in vitro investigation indicates that lycopene can influence the cell adhesion and migration properties of cancer cells at a dose which is arguably achievable in patients. The results of our study expand our understanding of a chemo preventive role of lycopene in prostate cancer.
\end{abstract}

Key words: lycopene, prostate cancer, cell adhesion

\section{Introduction}

Prostate cancer is the most common male cancer in the Western society. Although genetic predisposition is an important contributing factor, diet and lifestyle are suggested to play a significant role, especially in sporadic cancer [1]. The cancer preventive role of tomatoes was first highlighted by a large epidemiological study in 1995, suggesting them as a strong dietary predictor of reduced prostate cancer risk [2] and attributing their protective effect to lycopene. Several modes of action have been proposed for this effect (see review by Karin Wertz for further details) [3]. These include its ability to inhibit prostate cancer cell proliferation, alteration of cell cycle progression, inhibition of androgen activation and signalling, improved gap-junction communications, inhibition of IGF-1 and anti-angiogenic activity [4]. Adhesion to extracellular matrix (ECM) and motility of tumour cells within the ECM are important steps in the invasion progress of metastatic tumour cells. Previous studies have shown an inhibitory effect of lycopene in SK Hep-1 hepatoma cells, however the concentrations used were much higher than can be achieved in vivo $[5,6]$. Lycopene's effect on the adhesion and migration properties of prostate cancer cells has not been reported before.

In the present study, physiologically relevant 
concentrations of lycopene were tested for their effects on the migratory and adhesion properties of prostate cancer cell lines.

\section{Methods}

PC3 (ECACC) and DU145 (ATCC) prostate cancer cell lines, both androgen independent and exhibiting metastatic properties in vivo, were investigated. The immortalised normal prostate epithelial cell line PNT2 (ECACC) was also used. An all-E $>95 \%$ pure isomer of synthetic lycopene (DSM, Nutritionals) was tested. Crystalline lycopene was dissolved in tetrahydrofuran (THF) containing $0.025 \%$ butylated hydroxytoluene. The final solvent concentration was kept constant across all treatments (including controls) at a concentration of $0.1 \%$, chosen as having a minimal effect on cell viability.

\section{Cell Adhesion Assay}

Cells were grown in T25 cell culture flasks to $\sim 60 \%$ confluence, when lycopene was applied at 0 , $0.58,1.15$ and $2.3 \mu \mathrm{mol} / \mathrm{L}$ in serum free medium. Flasks were incubated for 24 hour in $5 \% \mathrm{CO}_{2}$ at $37^{\circ} \mathrm{C}$. Following treatment, cells were washed $2 x$ with PBS and detached using $3 \mathrm{ml}$ EDTA $(0.02 \%)$. They were suspended in fresh culture medium at a concentration of $5 \times 10^{4}$ cells $/ \mathrm{ml}$ and $0.1 \mathrm{ml}$ seeded into Matrigel ${ }^{T M}$ (BD Biosciences) coated wells of 96-well plates. After 1 hour incubation at $37^{\circ} \mathrm{C}$, all wells were gently washed three times with PBS to remove unattached cells. The remaining adherent cells were left to settle for $18 \mathrm{~h}$ in serum free medium, at which time they were exposed to WST-1 reagent (Roche, Applied Science) as per manufacturer's specification for spectrophotometric assessment of cell numbers. The adhesion assays were carried out in triplicate for each of the cell lines on three different days and the effects of lycopene dose are presented relative to untreated controls showing means of three independent experiments.

\section{Migration Assay}

For the migration assay, ibidi ${ }^{\mathrm{TM}}$ culture inserts (Thistle Scientific Ltd, UK) were used. Briefly, the inserts consist of two chambers separated by a $0.5 \mathrm{~mm}$ divider, each chamber with a growth area of $0.22 \mathrm{~cm}^{2}$. The inserts were planted into $35 \mathrm{~mm}$ tissue culture dishes using sterile tweezers. Cell suspensions were prepared at $7-9 \times 10^{5}$ cells $/ \mathrm{ml}$ in medium, of which $70 \mu 1$ was transferred to each chamber. The cells were left to adhere and grow to $\sim 90 \%$ confluence. They were then exposed to $0,0.58,1.15$ and $2.30 \mu \mathrm{mol} / \mathrm{L}$ lycopene within the chambers for $24 \mathrm{~h}$, at which time the cells were $100 \%$ confluent, as required for the migration assay. At this stage, cells were arrested by addition of $10 \mu \mathrm{g} / \mathrm{L}$ mitomycin-C for 30 minutes to prevent further proliferation. In the case of the normal PNT2 cell line, cells treated with $10 \mu \mathrm{g} / 1$ mitomycin-C had migrated at a much slower rate than the PC3 cells. This was partly due to a loss in viability resulting from the cell-cycle arrest induced by the mitomycin-C and the dose applied to PNT2 cells was subsequently reduced from $10 \mu \mathrm{g} / 1$ to $2 \mu \mathrm{g} / 1$. However, since a concentration of $2 \mu \mathrm{g} / 1$ did not appear to have a significant inhibitory effect on the proliferation of DU145 and PC3 prostate cancer cell lines, a mitomycin-C concentration of $10 \mu \mathrm{g} / \mathrm{l}$ was used for these cell lines.

The dividing strip between the chambers was removed and images were acquired along the cell-free zone between time 0 and 24 hours. Cell migration was assessed using AngioSys V1.0 software (TCS Cellworks), measuring the area covered by the cells. The encroachment of the cell-free gap for each treatment was determined by comparing results to the $0 \mathrm{~h}$ time point. Experiments for each cell line were performed in triplicate.

\section{Statistical Analysis}

Pairwise comparisons were done using SPSS (PASW18) to test the difference between control and the lycopene treated cells and differences at a level of 0.05 deemed significant.

\section{Results}

\section{The Effect of Lycopene on Cell Adhesion}

Figure 1 shows the cell adhesion data for PC3, DU145 and PNT2, obtained using the WST-1 assay. Experiments for each cell line were carried out in triplicate on three different days and data points presented are means of the three independent experiments (i.e. average of 9 measurements) \pm SD.

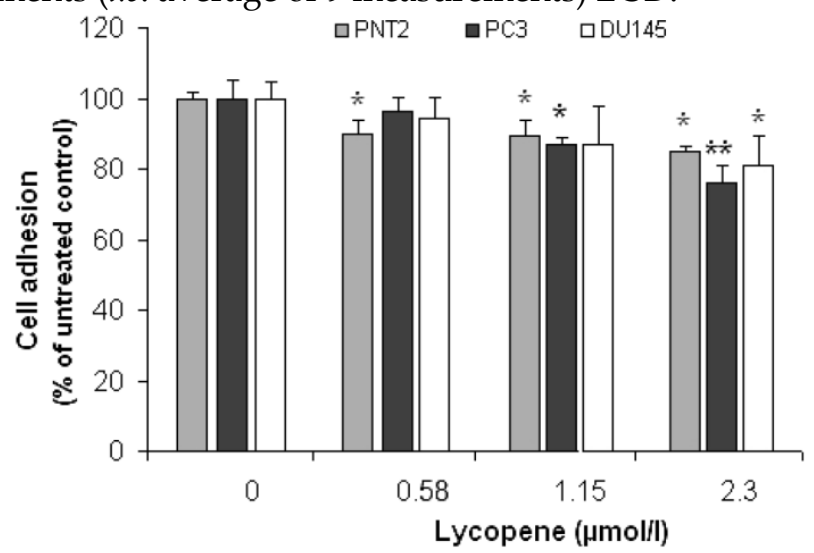

Figure I: Effect of Lycopene on prostate cell adhesion to Matrigel ${ }^{\mathrm{TM}}$. PC3, PNT2 and DUI45 cell-lines were pretreated with lycopene for 24h and then seeded into 96-well Plates precoated with Matrigel ${ }^{\text {TM }}$. The number of adhering cells was determined by WST Assay. The data points are presented as Means \pm SD of three separate experiments. The asterisk $(*)$ denotes significant difference from the untreated Control $(P<0.05)$. Double asterisk $(* *)$ indicates that this data point is also significantly different from the other treatment concentrations. 
At $2.3 \mu \mathrm{mol} / 1$, lycopene significantly reduced the attachment of all prostate cell lines to Matrigel ${ }^{\mathrm{TM}}$ (Figure 1). A significant inhibition of adhesion was also observed in PC3 cells at a lycopene concentration $\geq 1.15 \mu \mathrm{mol} / 1(P<0.05)$; however, it failed to reach statistical significance in the DU145 cell line. Lycopene also inhibited the adhesion of PNT2 cells, but the effect was the same at all lycopene concentrations and magnitude was lower.

\section{The Effect of Lycopene in the Cell Migration Assay}

There was a significant reduction in cellular migration of PC3 prostate cancer cells, both at 1.15 and
$2.3 \mu \mathrm{mol} / 1$ lycopene (Figure $2 \mathrm{a})$. The degree of inhibition was similar at lycopene concentrations of 1.15 and $2.3 \mu \mathrm{mol} / 1$. Treatment of DU145 cells with lycopene resulted in a more pronounced inhibition of migration compared to PC 3 cells (Figure $2 b$ ). In contrast, compared to the cancer cell lines, PNT2 cells migrated faster as shown by the merging of cell sheets within $24 \mathrm{~h}$ even in the presence of $1.15 \mu \mathrm{mol} / \mathrm{L}$ lycopene (Figure 2c and d). However, at a higher concentration there was some inhibition of migration in the presence of lycopene though magnitude was lower than the cancer cell lines.

\section{a Lycopene Treated PC3 cells}

Control
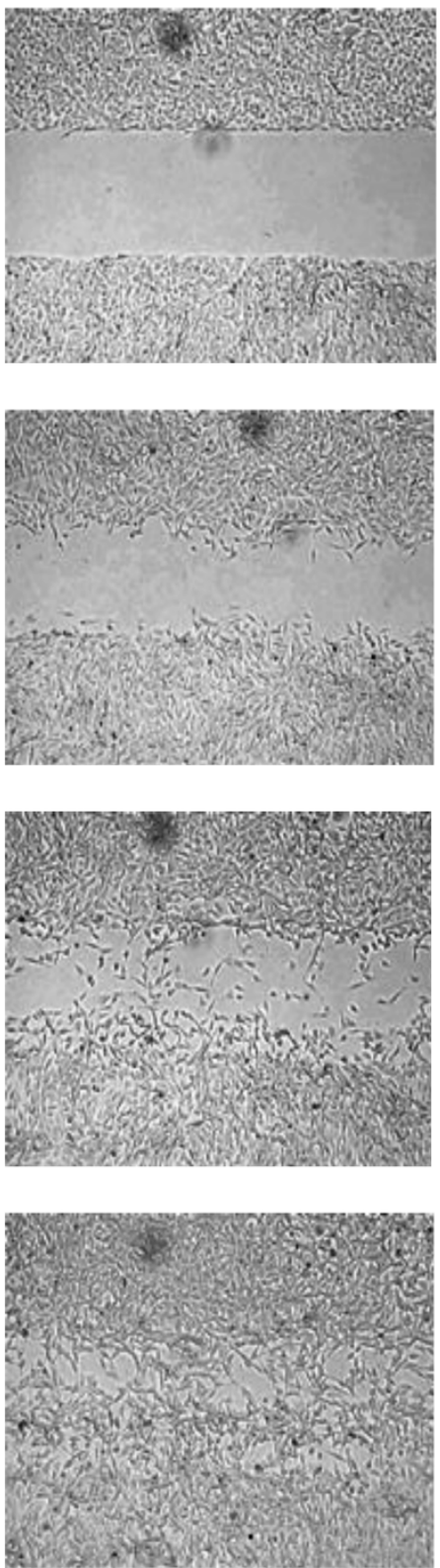

$1.15 \mu \mathrm{mol} / \mathrm{l}$
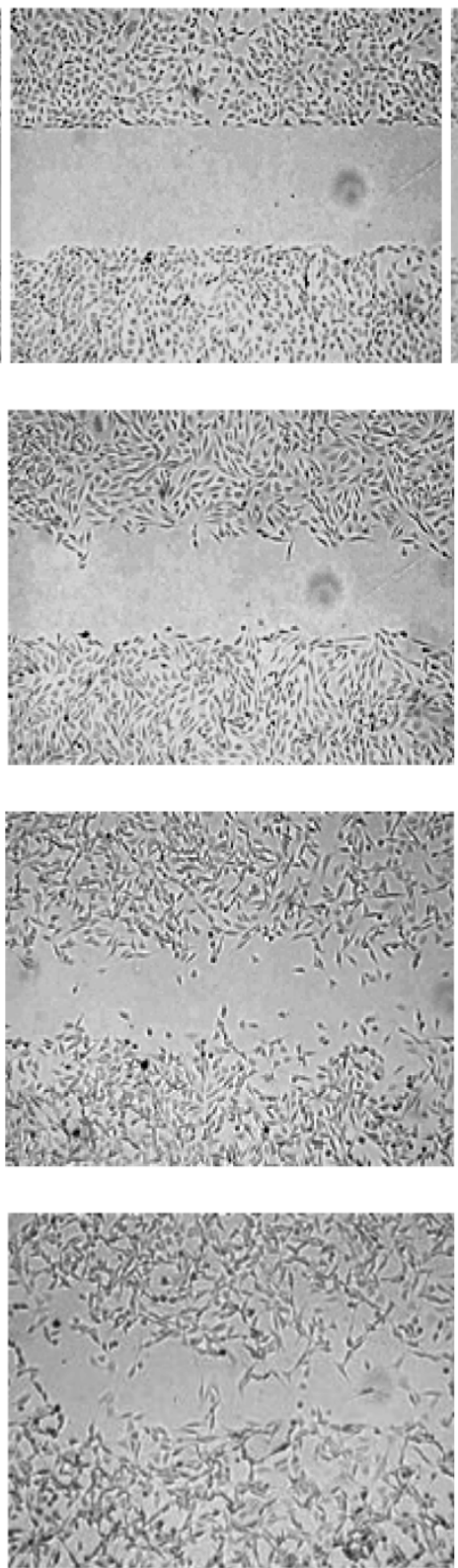

$2.3 \mu \mathrm{mol} / \mathrm{l}$
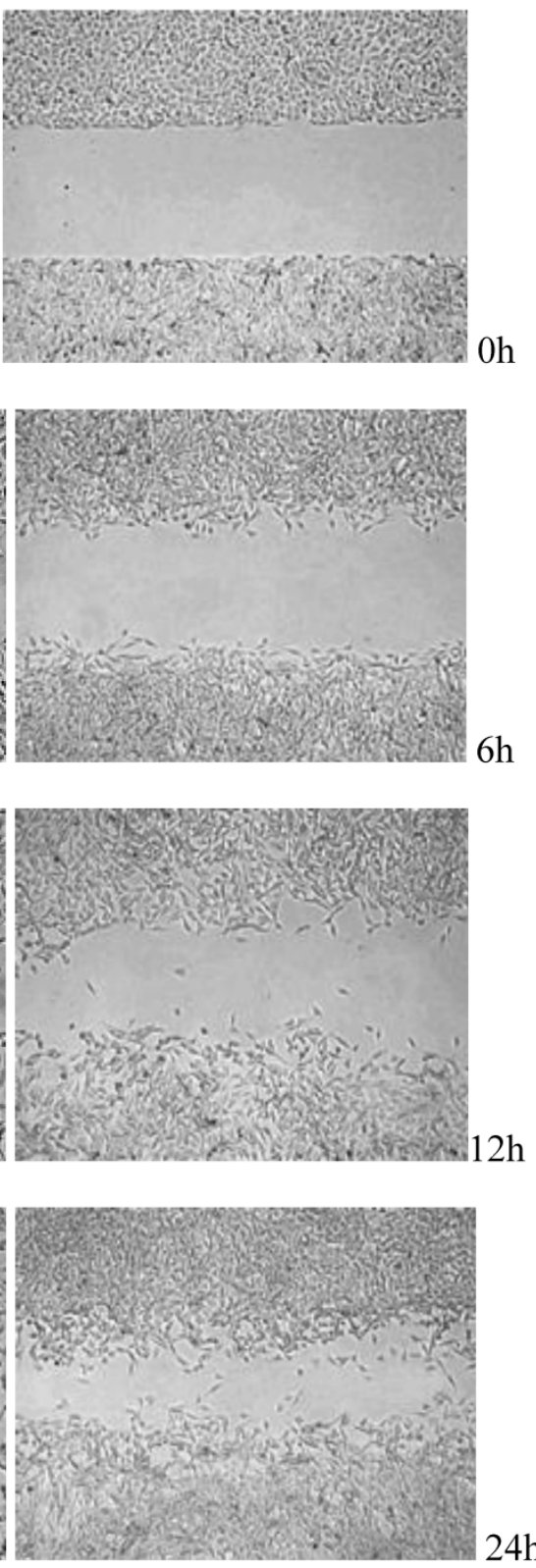


\section{b Lycopene Treated DU145 cells}

Control
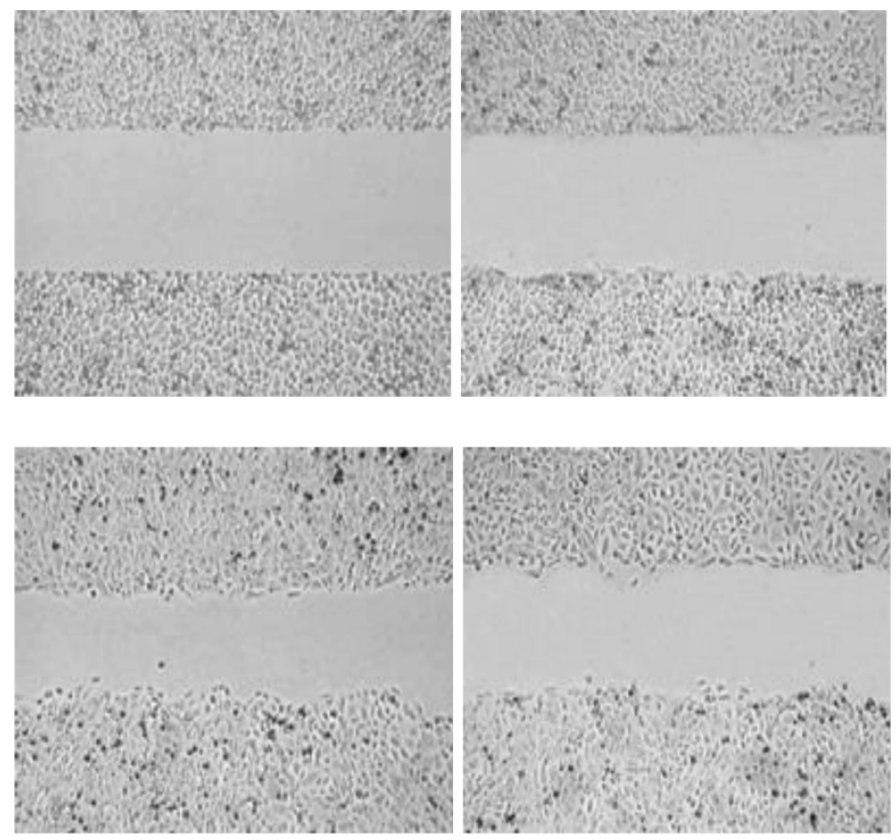

$1.15 \mu \mathrm{mol} / 1$

$2.3 \mu \mathrm{mol} / 1$
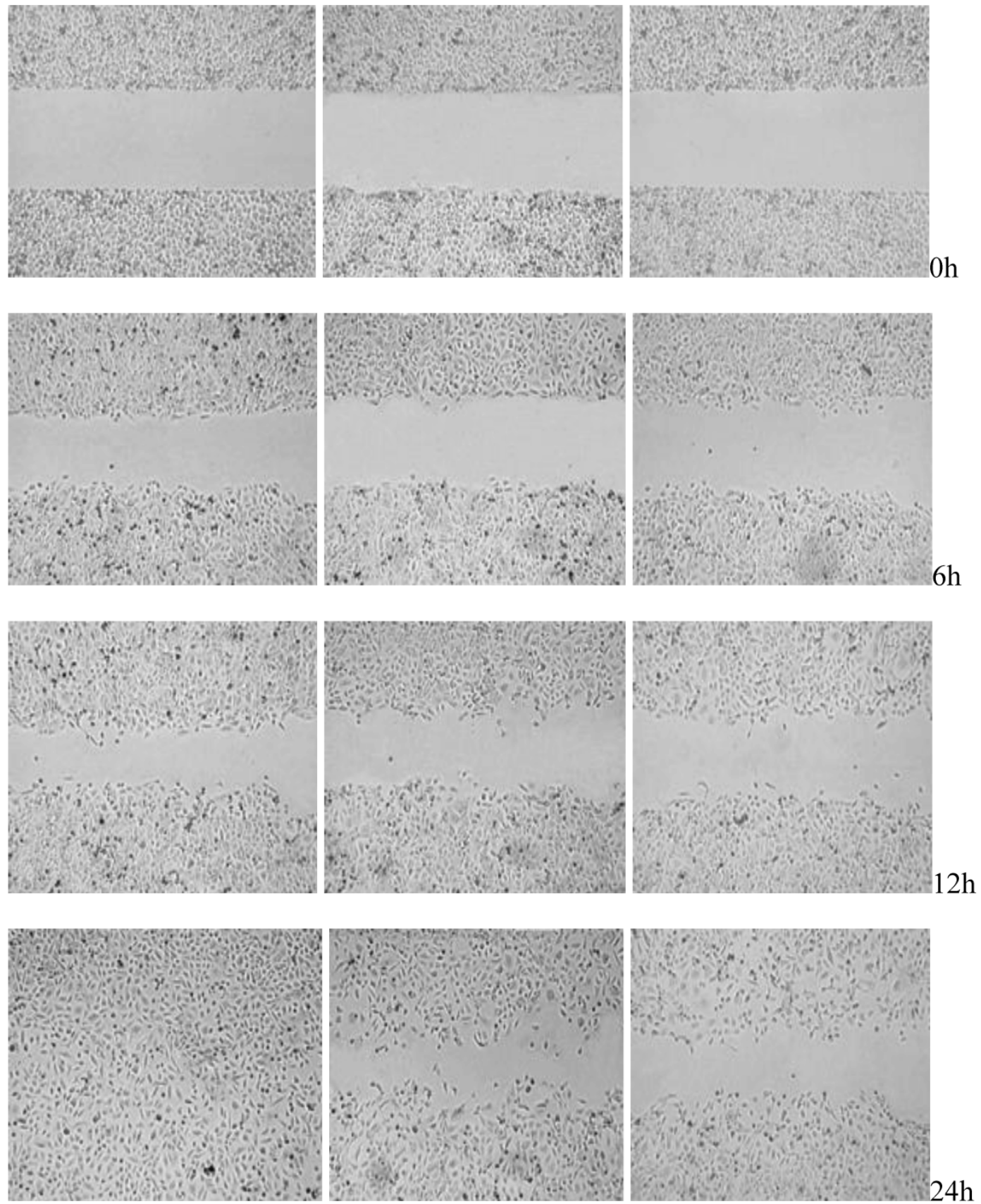


\section{Lycopene Treated PNT-2 cells}

Control
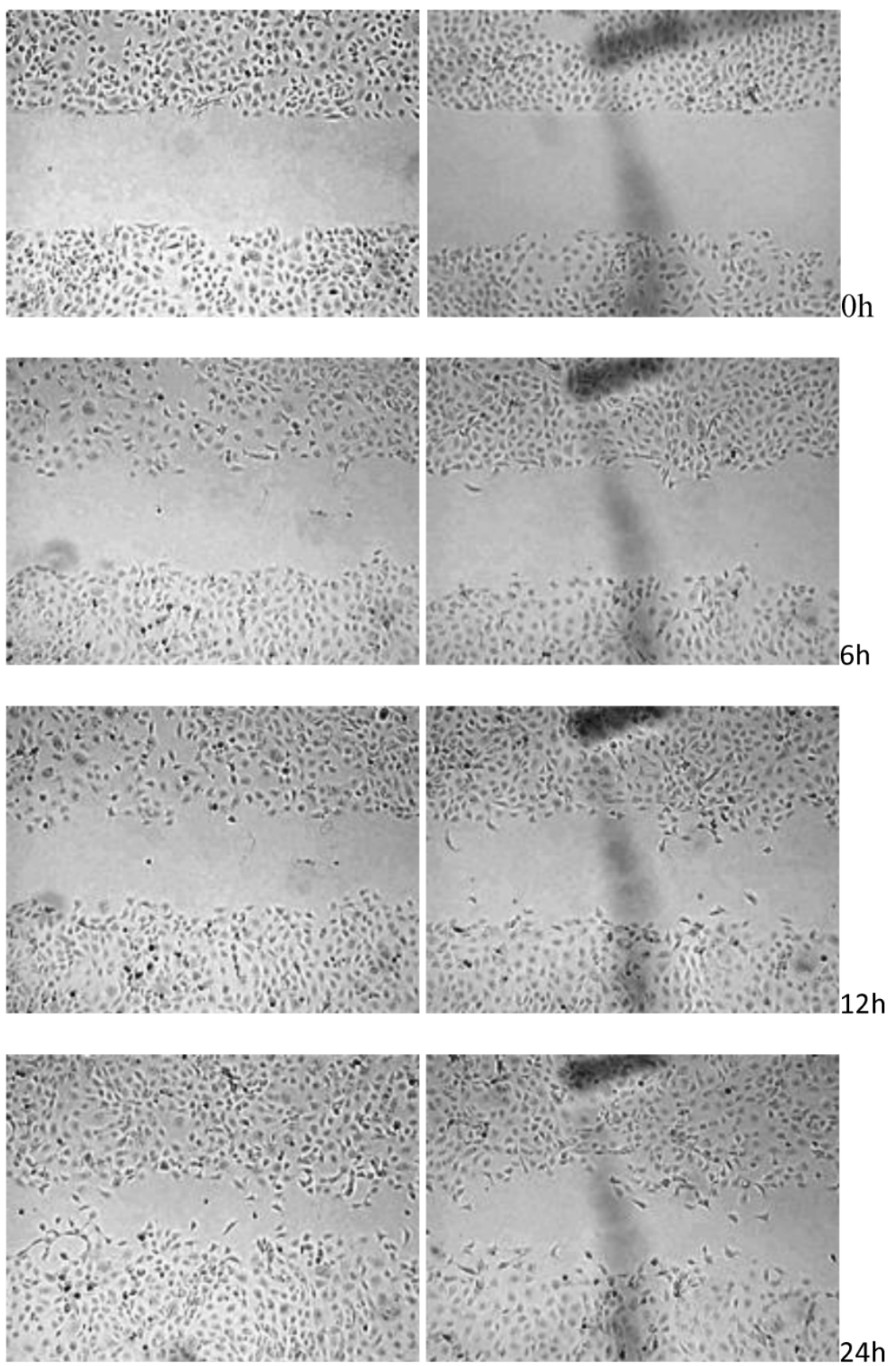


\section{d Lycopene Treated PNT-2 cells}

\section{Control}
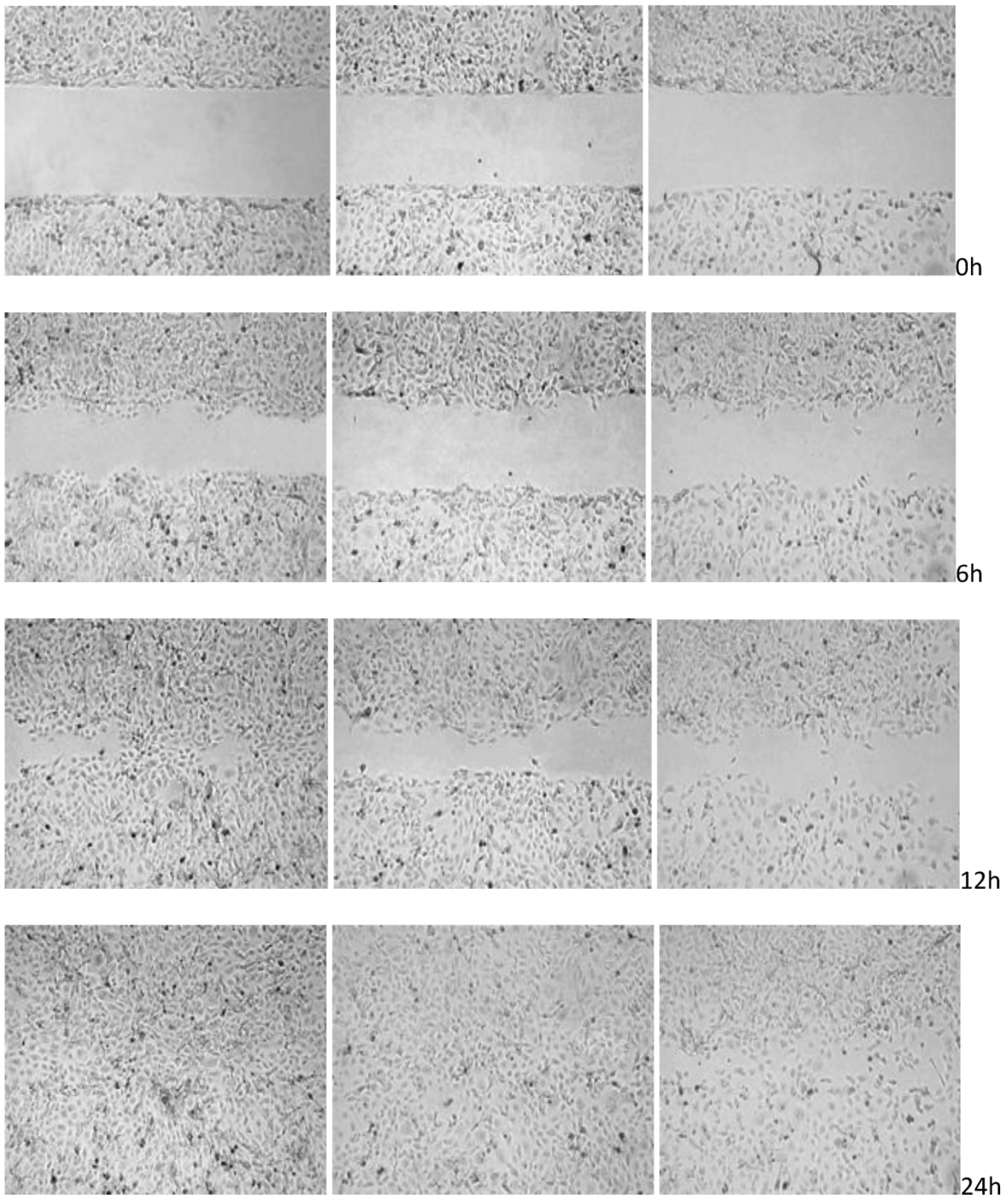

$24 \mathrm{~h}$

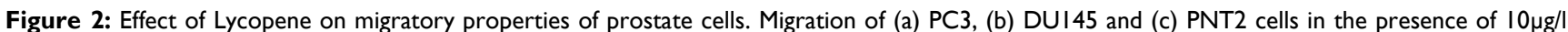
Mitomycin-C (d) PNT2 cells in the presence of $2 \mu \mathrm{g} / \mathrm{I}$ Mitomycin-C. Cells were grown to $80 \%$ Confluence in ibidi Culture Inserts and treated with $0, \mathrm{I} .15$ and $2.3 \mu \mathrm{mol} / \mathrm{I}$ Lycopene for $24 \mathrm{~h}$. $10 \mu \mathrm{g} / \mathrm{I}$ Mitomycin-C was used to arrest the cells and avoid further proliferation [in case of PNT2 cells, $2 \mu \mathrm{g} / \mathrm{I}$ Mitomycin-C was used (d), since a concentration of $10 \mu \mathrm{g} / \mathrm{I}$ Mitomycin- $C$ was found to be toxic to the cells (c)]. The culture inserts were then removed to reveal the gap and pictures were taken between $0-24 \mathrm{~h}$. Experiments were repeated three times.

\section{Discussion}

In the present study, lycopene inhibited adhesion of cancer cells to Matrigel ${ }^{\mathrm{TM}}$ as well as influenced the migratory properties of cancer cells at a physiologically relevant concentration of $1.15 \mu \mathrm{mol} / 1$. A sim- ilar effect was shown by Hwang and Lee in SK-Hep1 hepatocellular carcinoma cells [5]. However the lycopene concentration of $10 \mu \mathrm{mol} / 1$ used in their study exceeded our maximum concentration of $2.3 \mu \mathrm{mol} / 1$ lycopene. In our study, lycopene reduced motility rates of PC3 prostate cancer cells by up to $40 \%$ at 
concentrations as low as $1.15 \mu \mathrm{mol} / \mathrm{L}$. Lycopene showed maximum inhibition of adhesion in PC3 cells, however its anti-motility effect was more pronounced in DU145 with an overall inhibition of migration of $58 \%$ and $68 \%$ at final concentrations of 1.15 and $2.3 \mu \mathrm{mol} / 1$, respectively. To our knowledge, this is first study in which adhesion and migratory properties of aggressive prostate cancer lines have been studied at physiologically achievable concentrations of lycopene, i.e. $1-2 \mu \mathrm{mol} / 1$. It was interesting to see that lycopene showed only a small effect on the adhesion and migration properties of the immortalised normal prostate epithelial cell line PNT2.

Diagnosis as well as treatment of cancer is often preceded by years of cancer progression. At presentation, many patients may already have metastases. Identification of dietary components that can intercept the process in its early stages and knowledge of the concentration that is likely to be effective is therefore valuable. In our study, lycopene at a concentration of $0.58 \mu \mathrm{mol} / 1$ failed to affect adhesion and migration (results not shown) of prostate cancer cells. This helps explain why lycopene failed to show protective effects in cancer patients at plasma concentrations of $\sim 0.60 \mu \mathrm{mol} / 1[7,8]$. Lycopene demonstrated a significant inhibitory effect at $1.15 \mu \mathrm{mol} / 1$, though the effect on both adhesion and migration was more pronounced at a final concentration of $2.3 \mu \mathrm{mol} / 1$. This last concentration may be difficult to achieve in vivo, although one report suggests a rise in plasma lycopene to $2.08 \mu \mathrm{mol} / 1$ when participants consumed half a cup of tomato sauce daily for two weeks [9]. An increase in plasma concentrations to $\sim 1.15 \mu \mathrm{mol} / 1$ has been shown to be easily achievable in both healthy individuals and prostate cancer patients $[10,11]$. Results from our present study and a previous report [4] have shown that at above concentrations, lycopene can intercept the mechanisms important in metastasis. We therefore suggest that clinical intervention studies in cancer patients should select a dose of lycopene that is likely to increase plasma lycopene levels to more than $1.2 \mu \mathrm{mol} / \mathrm{L}$.

In conclusion, the present study provides in vitro evidence to support the previous clinical observations that reported lower incidence and less aggressive nature of prostate cancer in those who regularly consumed tomato based products. Our study also suggests concentrations at which biological effects of lycopene are likely to occur and are therefore relevant for further investigation into the clinical efficacy of this nutrient. Further studies are underway in our laboratory to examine the molecular pathways through which lycopene is likely to influence the invasive properties of cancer cells.

\section{Acknowledgements}

The authors would like to thank DSM Nutrition Products limited for their generous gift of the lycopene used in the present study.

\section{Competing Interests}

The authors have declared that no competing interest exists.

\section{References}

1. Wu K, Erdman JW, Schwartz ST, Platz EA, Leitzmann M, Clinton SK et al. Plasma and Dietary Carotenoids, and the Risk of Prostate Cancer: A Nested Case-Control Study. Cancer Epidemiol Biomarkers Prev 2004;13:260-269.

2. Giovannucci E, Ascherio A, Rimm EB, Stampfer MJ, Colditz GA, Willett WC. Intake of carotenoids and retinol in relation to risk of prostate cancer. J. Natl. Cancer. Inst. 1995;87:1767-1776.

3. Wertz K. Lycopene effects contributing to prostate health. Nutr Cancer 2009;61:775-783.

4. Elgass S, Cooper A, Chopra M. Lycopene inhibits angiogenesis in HUVECs and rat aortic rings. Br J Nutr 2012;108:431-439.

5. Hwang ES, Lee HJ. Inhibitory effects of lycopene on the adhesion, invasion and migration of SK-Hep1 human hepatoma cells. Exp Biol Med (Maywood) 2006;231: 322-327.

6. Huang C-S, Shih M-K, Chuang C-H, Hu M-L. Lycopene inhibits cell migration and invasion and upregulates Nm23-H1 in a highly invasive hepatocarcinoma SK-Hep1 cells. J Nutr 2005;135:2119-2123.

7. Puri T, Goyal S, Julka PK, Nair O, Sharma DN, Rath GK. Lycopene in treatment of high-grade gliomas: a pilot study. Neurol India 2010;58(1):20-23.

8. Kumar NB, Besterman-Dahan K, Kang L, Pow-Sang J, Xu P, Allen K et al. Results of a Randomized Clinical Trial of the Action of Several Doses of Lycopene in Localized Prostate Cancer: Administration Prior to Radical Prostatectomy. Clin Med Urol. 2008;1:1-14.

9. Allen CM, Schwartz SJ, Craft NE, Giovannucci EL, De Groff VL, Clinton SK . Changes in plasma and oral mucosal lycopene isomer concentrations in healthy adults consuming standard servings of processed tomato products. Nutr Cancer 2003;47:48-56.

10. Lee A, Thurnham DI, Chopra M. Consumption of tomato products with olive oil but not sunflower oil increases the antioxidant activity of plasma. Free Rad. Biol. Med. 2000;29:1051-1055.

11. Bowen P, Chen L, Stacewicz-Sapuntzakis M, Sharifi R, Ghosh L, van Breemen $\mathrm{R}$ et al. Tomato sauce supplementation and Prostate Cancer: Lycopene accumulation and modulation of biomarkers of carcinogenesis. Exp. Biol. Med. 2002;227:886-893. 